\title{
Evaluating the Variability of Sediment and Nutrient Loading from Riverine Systems into Texas Estuaries and Bays
}

The water quality in estuaries and bays and the health of these coastal ecosystems are affected by sediment and nutrient loads transported by streams. Large sediment loads delivered to an estuary or bay can degrade water quality. Concentrations of suspended sediment are affected by natural conditions (such as soil erosion and streambed resuspension) and can also be affected by human activities (such as development, timber harvesting, certain agricultural practices, and hydraulic alteration). An increased sediment load delivered to an estuary or bay can reduce water clarity and light penetration (Senus and others, $2005)$ in the water column. Senus and others $(2005$, p. 1) also note that

nutrients are needed to sustain life, but excess nutrient loads from human activities may cause unbalanced and unhealthy changes in water quality that are harmful to aquatic organisms. Nitrogen and phosphorus are two known nutrients of concern. Poor water quality caused by an abundance of these nutrients can stimulate the excessive growth of phytoplankton, promote algal blooms, reduce dissolved oxygen levels, and cause fish kills.

Approximately 60 percent of coastal rivers and bays in the United States have been moderately to severely degraded by excess nutrients (Howarth and others, 2002).

Water quality in rivers constantly changes in response to rainfall in the watershed, and increased sediment and nutrient loads in rivers often occur during periods of high flow (Hubbard and others, 2011; Maryland Department of Natural Resources,

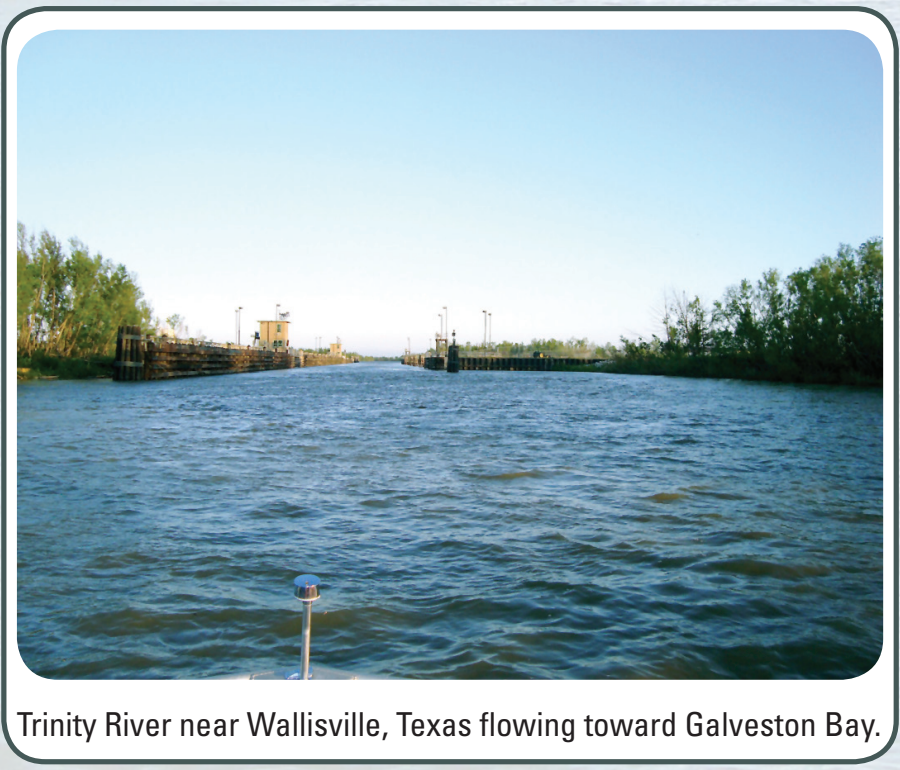

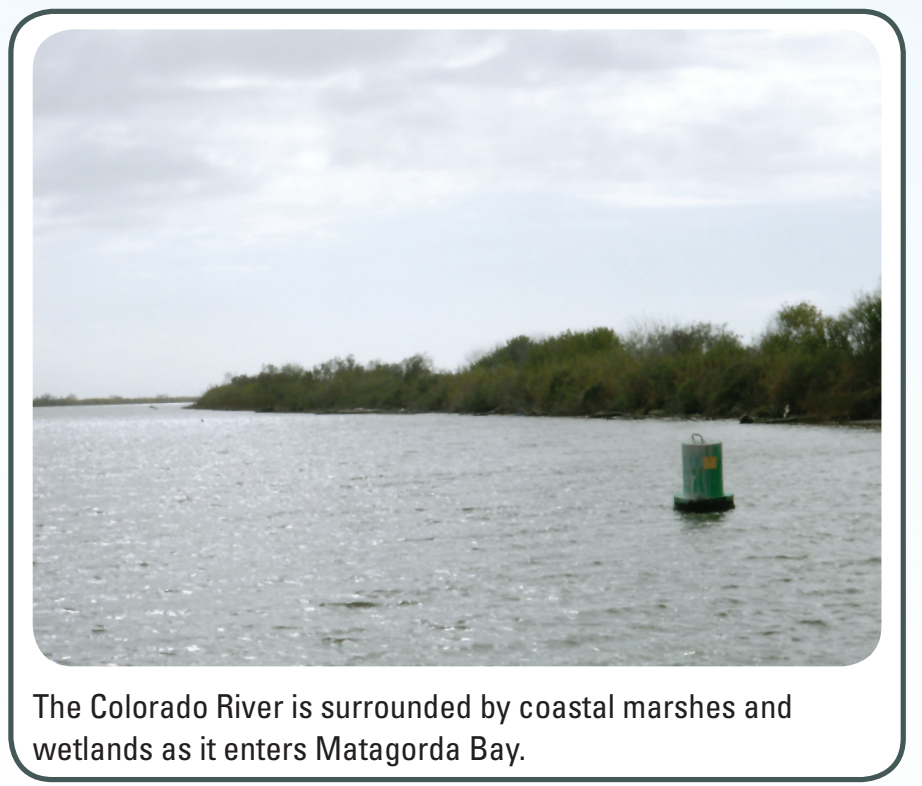

2011). In Texas, periods of high flow in rivers flowing into coastal ecosystems are usually caused by local rainfall or by releases from upstream reservoirs made in response to rainfall farther upstream in the basin (Galveston Bay Estuary Program, 2002). The increase in rain and resultant flooding can increase sediment erosion and nutrient runoff into coastal rivers and consequently increase sediment and nutrient input into estuaries and bays.

Flow, sediment, and nutrient data can be used for descriptive purposes as well as serving as input to hydrodynamic and water-quality models that aid the understanding of coastal ecosystems in Texas. At present (2011), these types of data are not widely available for many Texas estuaries, particularly during peak inflow periods, when large pulses of sediments and nutrients have the potential to substantially affect water quality and estuary and bay ecosystem health.

\section{Evaluating the Temporal Variability of Sediment and Nutrient Loads}

In 2009, the U.S. Geological Survey (USGS), in cooperation with the Texas Water Development Board (TWDB), began evaluating the variability of sediment and nutrient loads in the lower reaches of the Trinity River during a variety of hydrologic conditions. Discharge, sediment concentration and sand/fine break, and nutrient concentration data (including nitrate and phosphate concentrations) were collected at USGS streamflow-gaging station 08067252 Trinity River at 
Wallisville, Tex. (fig. 1), to gain a better understanding of the hydrologic and water-quality characteristics for the Galveston Bay coastal ecosystem (Lee, 2010). This ongoing study is designed to help characterize the sediment and nutrient load transported into Galveston Bay as related to localized periods of high flow and releases of water from reservoirs upstream in the watershed. As an extension of the data collection that began in 2009 on the Trinity River, the collection of similar sediment and nutrient data by the USGS, in cooperation with the TWDB, in the lower reaches of the Colorado River and San Jacinto River in Texas began in 2010-USGS streamflowgaging stations 08162506 Colorado River Bypass Channel near Matagorda, Tex., and 08072050 San Jacinto River near Sheldon, Tex. (fig. 1). In addition to collecting suspended-sediment and nutrient samples to improve understanding of the amounts of sediment and nutrients entering into the Matagorda Bay and Galveston Bay estuary, periodic bedload samples are collected from the lower Colorado River site and the San Jacinto River site, respectively. The bedload data will help provide a better understanding of the contribution of bedload sediment to total sediment discharges.
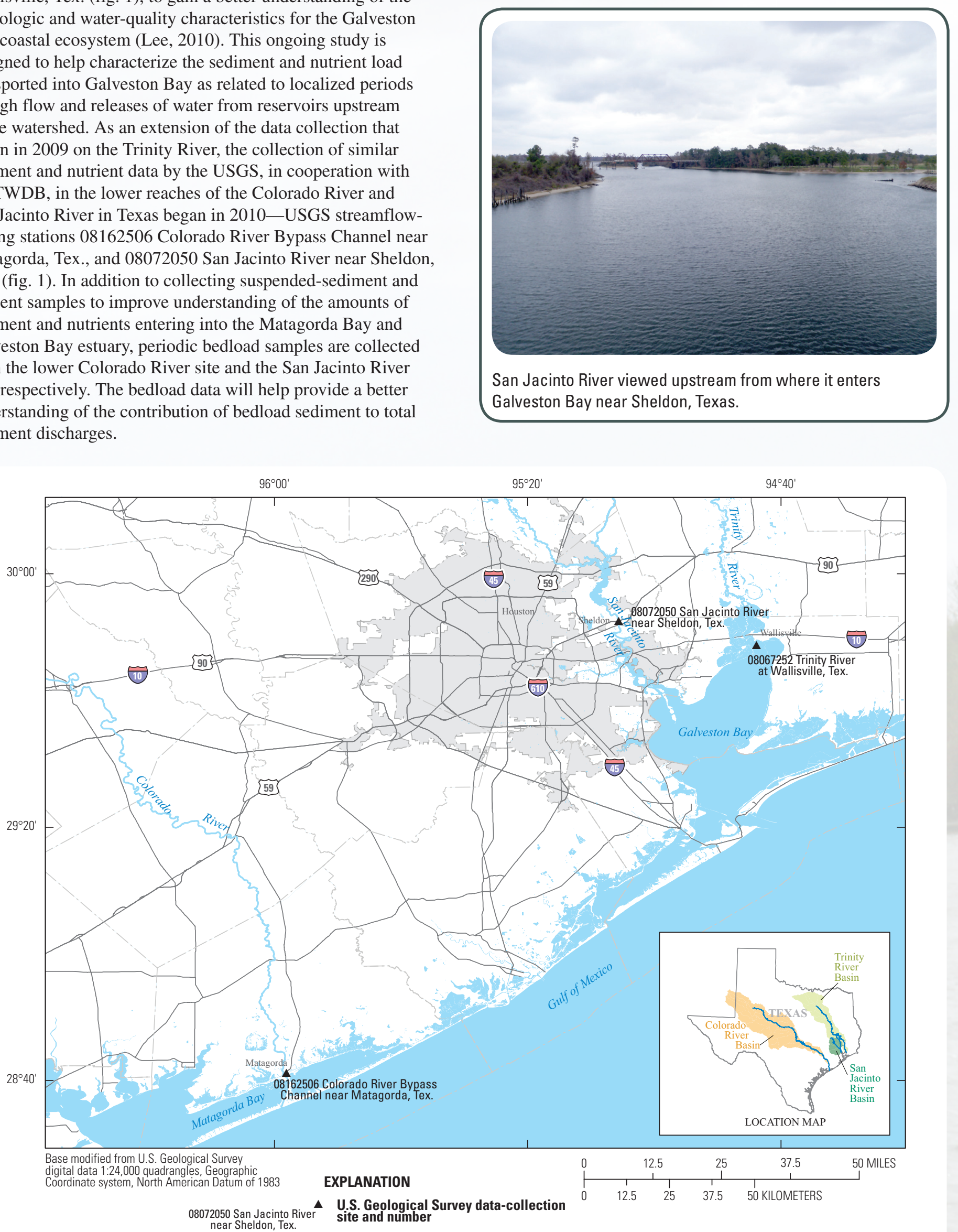

Figure 1. Location of data-collection sites on the Trinity River and San Jacinto River upstream from Galveston Bay and on the Colorado River upstream from Matagorda Bay, Texas. 


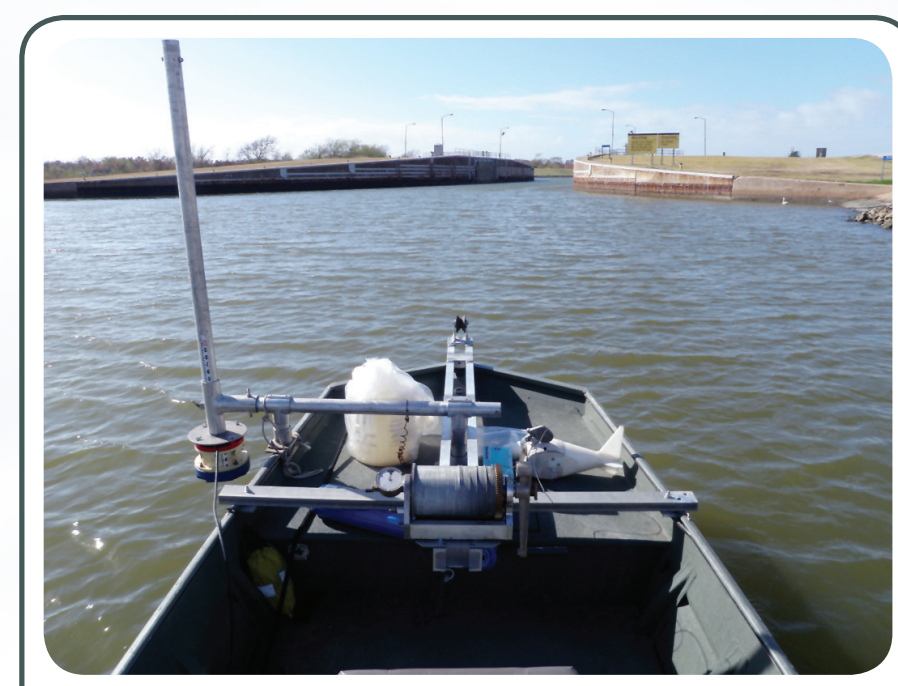

Side-mounted $A D C P$ and water-quality sampling equipment on a U.S. Geological Survey work boat used for coastal studies.

\section{Sample Collection}

Criteria for the timing of sample collection are developed on the basis of historical streamflow in each basin. Particular emphasis is placed on high-flow events, but samples over the entire hydrograph range are collected to evaluate the temporal variability of sediment and nutrient loading to the coastal system.

Physical water-quality properties (water temperature, specific conductance, $\mathrm{pH}$, dissolved oxygen concentration, and turbidity) are measured at the sampling site by using a water-quality multiprobe instrument at the time of sampling. Discharge measurements of the stream are made prior to the collection of each sample by using an acoustic Doppler velocity meter as described in Mueller and Wagner (2009).

Discrete water-quality samples are routinely collected and analyzed for selected unfiltered and filtered constituents. These selected unfiltered constituents include suspended-sediment,

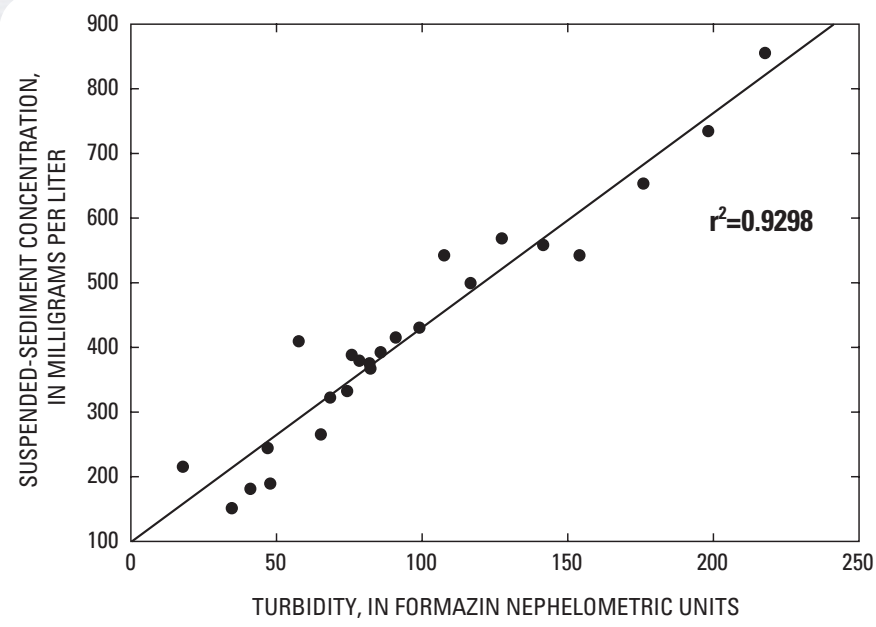

Figure 2. Correlation between suspended-sediment concentration and turbidity during two periods of high flow, April 20-23, 2009, and September 22-November 3, 2009, at 08067252 Trinity River at Wallisville, Texas. total phosphorus, and total nitrogen concentrations. Filtered constituents include selected nutrients (filtered ammonia, filtered nitrate plus nitrite, filtered nitrite, and filtered orthophosphate concentrations).

Water-quality samples are collected and processed following standard USGS sampling methods as described in the "National Field Manual for the Collection of Water-Quality Data" (U.S. Geological Survey, variously dated). Depth integrated sampling is done along a river cross section to capture variability of constituent concentration within the river by using the equal discharge increment (EDI) approach (Edwards and Glysson, 1998). All nutrient samples are analyzed by the USGS National Water Quality Laboratory in Lakewood, Colo. Suspended-sediment samples are analyzed by the USGS Kentucky Water Science Center Sediment Laboratory in Louisville, Ky., for suspended-sediment concentration and particle-size distribution. Since 2010, the periodic bedload samples collected from the lower Colorado River and San Jacinto River sites have also been analyzed by the Kentucky Water Science Center Sediment Laboratory for particle-size distribution.

\section{Preliminary Results}

Two periods of high flow on the Trinity River were initially evaluated in 2009 to assess the variability of sediment and nutrient data, and variations in loading caused by differences in flood-discharge magnitude and duration, origin of initial floodwater runoff, and timing of sample collection. The two periods of high flow had different flood and nutrient loading characteristics. Suspended-sediment, total nitrogen, and total phosphorus concentrations were compared to selected physical properties measured in place. These data indicate a relation exists between suspended-sediment concentrations measured in discrete waterquality samples and measured turbidity values (fig. 2). A similar relation exists between total nitrogen concentrations and turbidity and between total phosphorus concentrations and turbidity (fig. 3).

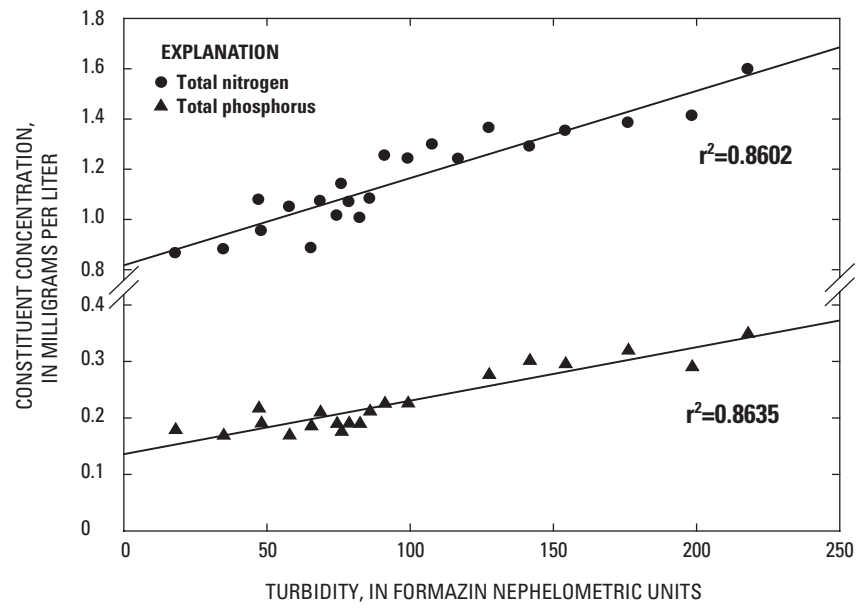

Figure 3. Correlation between total nitrogen or total phosphorus concentration and turbidity during two periods of high flow, April 20-23, 2009, and September 22-November 3, 2009, at 08067252 Trinity River at Wallisville, Texas. 
The initial sediment and nutrient loading estimates from the Trinity River to Galveston Bay indicate that discrete and continuous water-quality data can be used to make load estimates for sediment and nutrients. Additional data are needed to confirm the preliminary results. With a better understanding of the loads of these constituents, it might be possible to better understand the role sediment and nutrient loads have on the ecological health of other Texas estuaries and bays.

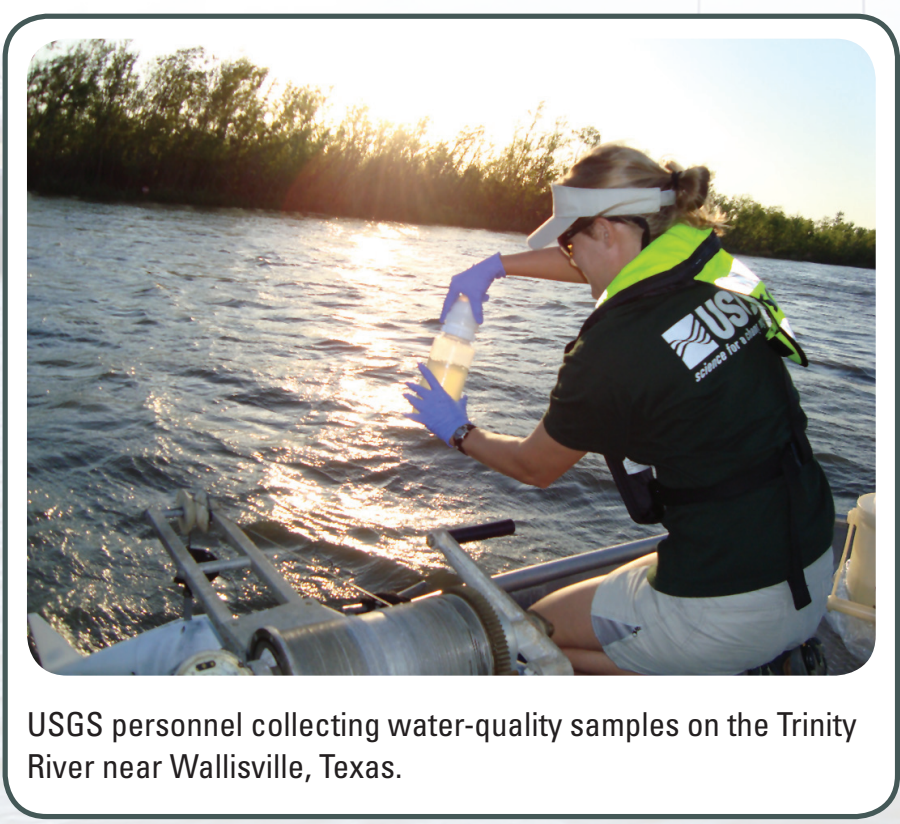

\section{References}

Edwards, T.K., and Glysson, G.D., 1998, Field methods for measurement of fluvial sediment: U.S. Geological Survey Techniques of Water-Resources Investigations, book 3 , chap. C2, 80 p.

Galveston Bay Estuary Program, 2002, The state of the bayA characterization of the Galveston Bay ecosystem ( $2 \mathrm{~d}$ ed.): Galveston Bay Estuary Program GBEP-T7, chaps. 5-6.

Howarth, R.W., Sharpley, Andrew, and Walker, Dan, 2002, Sources of nutrient pollution to coastal waters in the United States-Implications for achieving coastal water quality goals: Estuaries, v. 25, no. 4b, p. 656-676.

Hubbard, L., Kolpin, D.W., Kalkhoff, S.J., and Robertson, D.M., 2011, Nutrient and sediment concentrations and corresponding loads during the historic June 2008 flooding in eastern Iowa: Journal of Environmental Quality, v. 40, p. 166-175.

Lee, M.T., 2010, A preliminary evaluation of Trinity River sediment and nutrient loads into Galveston Bay, Texas, during two periods of high flow, in Second Joint Federal Interagency Conference (Ninth Federal Interagency Sedimentation Conference and Fourth Federal Interagency Hydrologic

Publishing support provided by

Lafayette Publishing Service Center

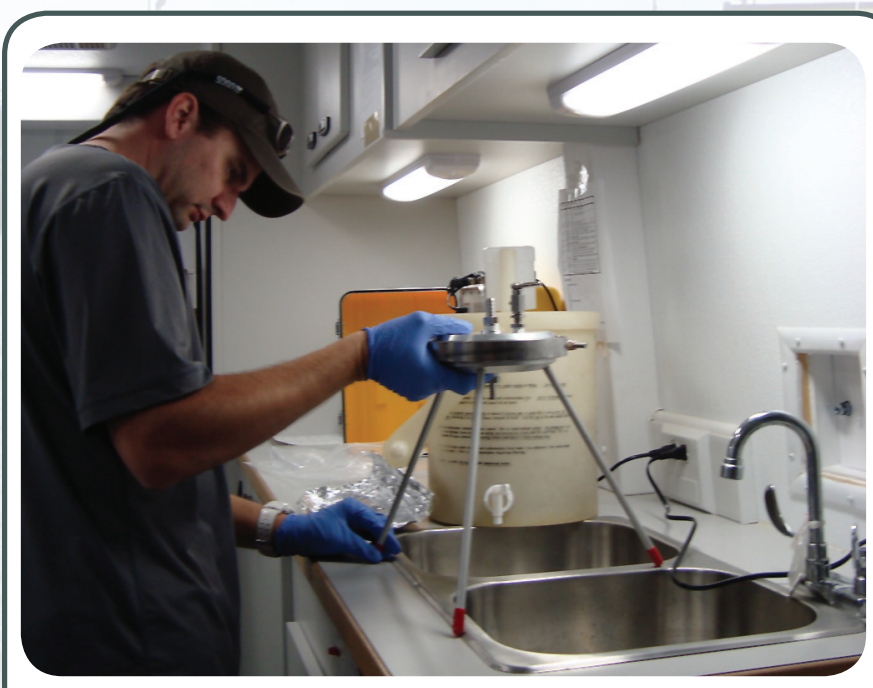

USGS personnel processing water-quality samples for sediment and nutrient data.

Modeling Conference), Las Vegas, Nevada, June 27-July 1, 2010, Proceedings: 12 p.

Maryland Department of Natural Resources, 2011, Chesapeake Bay monitoring-Monitoring for management actions: accessed February 9, 2011, at http://www.dnr.state.md.us/bay/ monitoring/mon_mngmt_actions/chapter8.html.

Mueller, D.S., and Wagner, C.R., 2009, Measuring discharge with acoustic Doppler current profilers from a moving boat: U.S. Geological Survey Techniques and Methods 3A-22, 72 p., accessed February 19, 2010, at http://pubs.water.usgs. gov/tm3a22.

Senus, M.P., Langland, M.J., and Moyer, D.L., 2005, Nutrient and sediment concentrations, loads, and trends for four nontidal tributaries in the Chesapeake Bay watershed, 1997-2001: U.S. Geological Survey Scientific Investigations Report 2004-5125, 33 p.

U.S. Geological Survey, variously dated, National field manual for the collection of water-quality data: U.S. Geological Survey Techniques of Water-Resources Investigations, book 9, chaps. A1-A9, accessed February 19, 2010, at http://pubs.water.usgs.gov/twri9A.

\section{-Michael T. Lee}

For additional information, contact
Director
USGS Texas Water Science Center
http://tx.usgs.gov/
gs-w-txpublic-info@usgs.gov

